\title{
Tax Evasion in Brazil and the Institutions to Control
}

\author{
Felippe Clemente (Corresponding author) \\ Postdoctoral Researcher in Economics, Economics Department \\ Federal University of Viçosa, Brazil \\ Email: felippe.clemente@ufv.br
}

Viviani Silva Lírio

Associated Professor, Rural Economics Department

Federal University of Viçosa, Brazil

Received: January 28, 2017 Accepted: February 18, 2017 Published: March 07, 2017

doi:10.5296/ijafr.v7i1.10679 URL: http://dx.doi.org/10.5296/ijafr.v7i1.10679

\begin{abstract}
Brazilian tax evasion is very high. Tax evasion cause many problems for economics as budget realization, income distribution and not allocation of productive resources. The tax authority and the government have tried developing mechanisms for down the tax evasion agent action. However, the problem in Brazil is not having a real and security database about tax evasion. This paper is a first effort for try to measure and to identify tax evasion in Brazil. Despite efforts to the fight against crimes pension Brazil faces several problems regarding the decreased levels of tax evasion in the country, the main structural nature such as soft laws, lack of skilled labor, inefficient methods of preventive combat and academic research.
\end{abstract}

Keywords: Tax evasion, Brazil, Institutions 


\section{Macrothink \\ International Journal of Accounting and Financial Reporting \\ ISSN 2162-3082 \\ 2017, Vol. 7, No. 1}

\section{Introduction}

Social actions of the State needs financial resources and taxes offer financial support to use for increase societal welfare. For that, persons and firms are taxed with many types of taxes.

However, when this cycle is broken and State does not offer services and goods for people, emerge the tax evasion problem. Tax evasion is an interdisciplinary term and can be studied for many sciences fields. Law may to study mechanisms for become easier tax payment. Business administration and Accounting can to help firms and industries pay less tax and increase their market participation. Economics can propose efficient methods for State and increased detection of tax evasion.

Problem of tax evasion is common in many countries. Developed countries as Germany, England and USA have low taxes, but firms and industries tax evade for increase their profit. In the other hand, developing countries as Russian, Chile and Brazil have high taxes and firms are stimulates tax evade for survive in the market.

Moreira (2003) shows Brazilian tax evasion is equal to 40\%. Russian and Chile had 42,7\% and $26 \%$ for tax evasion and, in compare, USA had $17 \%$ in 2000.

Alexandre (2013) said taxes are created only in law. So, in a democracy, as law is approved by people represents, can be mentioned that people pay only choice taxes them. Then, tax evasion is considerate a crime and Brazil fight with it since 1980.

Tax evasion cause many problems for economics as budget realization, income distribution and not allocation of productive resources. It is necessary decrease tax evasion in Brazil to construct a country more just and modern.

The tax authority and the government have tried developing mechanisms for down the tax evasion agent action. However, the problem in Brazil is not having a real and security database about tax evasion.

This paper is a first effort for try to measure and to identify tax evasion in Brazil. The main goal of this work is to know the amount of tax evasion in Brazil and its consequences to purpose policies that decrease tax evasion. Furthermore, is interesting to know public Brazilian Institutions for confront of tax evasion agent.

\section{Theoretical Reference}

The existences of the institutions are necessary in a complex economics system. It gives directions, correct and completes Market system what do not get to make all activities alone. The government actions are made by fiscal policy: allocative function, distributive function and stabilization function. Allocative function choice type and quantity of public goods offer. Distributive function realizes equal income distribution and stabilization function uses economic policy for guarantee a good behavior of economics (GIAMBIAGI, 2002). 


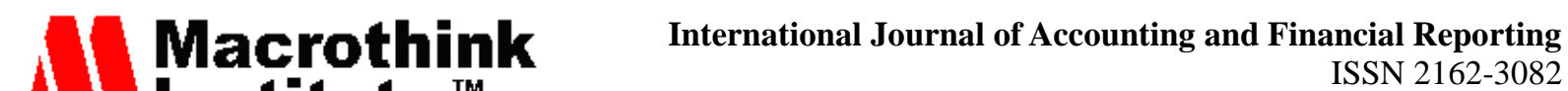 2017, Vol. 7, No. 1}

\subsection{Tax Theory}

The main government resource is taxes. Alexandre (2013) shows State tax to get financial support for its policies and welfare social. Brazilian Taxes Code (CTN) defines taxes as:

“Art. $3^{\circ}$ Tributo é toda prestação pecuniária compulsória, em moeda ou cujo valor nela se possa exprimir, que não constitua sanção de ato ilícito, instituída em lei e cobrada mediante atividade administrativa plenamente vinculada"1.

The Tax Theory has three main fundamental principles: Neutrality, Equality and Simplicity. Neutrality principle consist in a not intervention from government in the private market. Equality principle goals same treatment for individuals or firms and Simplicity principle consist on to became easier the tax payment (GIAMBIAGI, 2002). Taxes that do not follow these principles indicate risks for society, as welfare loses and evasion.

At this context, in 1974, Laffer created a graphic to show the ambiguous relation between taxes increases and tax authority profit. Basic principles of this theory are: i) a tax rate equal to zero implies on a zero profit; ii) a tax rate equal to $100 \%$ implies on a zero profit too. Then, there is an optimal rate level that maximizes the tax authority profit. After this level, high tax rate cause tax evasion and/or decrease of formal activities in economics that implies in less profit. (Figure 1).

Figure1: Laffer curve ${ }^{2}$.

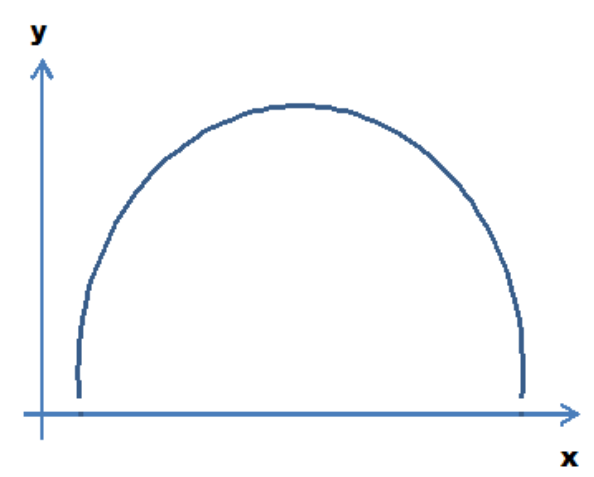

Source: By authors

Government can tax directly or indirectly the taxes payers. Direct taxes are link with payment conditions of payers. Revenue taxes are examples of direct taxes and follow equality and progressivity principles. Sales taxes are examples of indirect taxes and do not link the taxes with payment conditions of payers.

\footnotetext{
1 "Art. $3^{\circ}$ Taxes are all money compulsory provision or things that has value, cannot be formed by illegal action, written in the law and charged by official public administrative".

${ }^{2}$ At Figure, $y$ represents the tax authority profit and $x$ represents the taxes rate.
} 


\subsection{Theory of Tax Obligation}

Martins (1998) said tax obligation is State power for create law and rules to appropriate of a part of families wealth and, then offer public goods or there.

However, tax law is rejected for society and people probably will not pay it if: the tax rate is high, the tax is unjust and there is not tax authority to obligate the payment. Therefore, taxes laws are elaborate by three pillars: tax obligation, punishment and punishment within taxes.

VILLEGAS apud MARTINS (1998), shows that punishment is a consequence by does not tax pay and said:

"No nosso tempo e nas modernas ordenações estatais, a praga da evasão impõe medidas repressivas adequadas, por mais que se continue considerando utópica qualquer pretensão de extirpá-la. Concordamos em sustentar que a evasão tributária deve ser implacavelmente perseguida $^{3}$ ".

It is possible observe that tax obligation aims to punish tax evasior and, for that, State needs use its police power to find and to punish the evasior agents.

\subsection{Societal Institutions}

A first institution is what might be termed the 'social norm' of compliance. A social norm represents a pattern of behavior that is judged in a similar way by others and that therefore is sustained in part by social approval or disapproval. Consequently, if others behave according to some socially accepted mode of behavior, then the individual will behave appropriately; if others do not so behave, then the individual will respond in kind (Elster, 1989).

Under this perspective suggests the government can affect a social norm of compliance, and then such government policies represent another, potentially significant tool in the government's battle with tax evaders. Of course, policies to change the social norm of compliance are difficult to determine in theory. However, there is some evidence from various social sciences that suggests that these norms can be affected by government institutions and policies. For example, there is much behavioral science evidence that implies that greater individual participation in the decision process will foster an increased level of compliance, in part because participation implies some commitment to the institution and such commitment in turn requires behavior that is consistent with words and actions (Alm and Martines-Vazquez, 2003).

A dimension by which social norms can be changed is the government's commitment to enforcing the tax laws. In fact, it seems likely that there is a constant interaction between social norms and tax administration. If the perception becomes widespread that the government is not willing to detect and penalize evaders, then such a perception legitimizes tax evasion. The rejection of sanctions sends a signal to each individual that others do not wish to enforce the tax laws and that tax evasion is in some sense socially acceptable, and the social norm of compliance disappears.

\footnotetext{
${ }^{3}$ Actually, the problem of tax evasion needs of repression rules, knowing it is impossible extinguish its. Likely tax evasion need to be countered.
} 
According to Alm and Martines-Vazquez (2003) a second institution is the administrative machinery of the government tax agency. Tax administrators and practitioners in a long list of country studies have long recognized the administrative dimension of taxation, and economists working on tax policy in developing countries (Goode, 1981; Bird, 1989) have frequently flagged it. A tax administration exists to ensure compliance with the tax laws, and much of the discussion of tax administration is consistent with the economics-of-crime approach discussed earlier. However, as emphasized by Bagchi et al. (1995), it is helpful to view the tax administration process somewhat more broadly, as a production function in which 'inputs' like personnel, materials, information, laws and procedures are used to produce several 'outputs', the most important of which is government revenue, but which also includes taxpayer satisfaction, equity and social welfare.

With these goals in mind, tax administration reform in DTCs emphasizes a variety of measures, including such traditional policies as: i) introducing an effective audit program that identifies individuals who do not file tax returns as well as those who under-report income or over claim deductions and credits; ii) applying non-harsh penalties often and consistently; iii) using source-withholding whenever possible; and iv) facilitating payments through the banking system.

These inputs view the taxpayer as a potential criminal who must be deterred from cheating. However, it is increasingly the case that inputs are not limited to these traditional enforcement mechanisms. Instead, tax administrations in many developing countries are also introducing policies that emphasize the provision of taxpayer services via such things as: i) promoting taxpayer education and developing taxpayer services to assist taxpayers at every step in filing returns and paying taxes; ii) broadcasting advertisements that link taxes with government services, iii) simplifying taxes and the payment of taxes; iv) promoting voluntary compliance by lowering the costs for taxpayers associated with filing their taxes; v) ensuring relative stability of the tax system

\section{Methodology}

As Oliveira (2012), the methodology adopted in the research depends directly on the object under study, its nature, scope and objectives of the scientist. In General, the researchers' intention is not only to describe but also to understand the phenomena and, therefore, becomes necessary to collect data to show the phenomenon intelligible form.

Vergara (2009) proposes two basic criteria for the classification of research: one on the purposes and the other as to the means of investigation. As for the purpose, the research can be exploratory, descriptive, explanatory, methodological, applied or interventionist. As for the means of research, the research can be field, laboratory, documentary, bibliographic, experimental, participant action research or case study.

The exploratory research aimed at providing greater familiarity with the problem in order to make it more explicit or build hypotheses. You could say that these researches have as main objective the improvement of ideas or the discovery of intuitions. By its nature, probing does not carry hypotheses, which, however, may arise during or at the end of the survey. 


\section{Macrothink}

International Journal of Accounting and Financial Reporting

ISSN 2162-3082

2017, Vol. 7, No. 1

Descriptive research has as its primary objective the description of the characteristics of a given population or phenomenon and then establishing relationships between variables. Have no commitment to explain the phenomena he describes, though as a basis for such explanation. The explanatory research has as main objective to make something intelligible, justified its motives. Are considered the most complex and are characterized by a main concern of identifying or determining factors that contribute to the occurrence of phenomena. It is the kind of research that deepens the knowledge of reality, it explains the reason why things (VERGARA, 2009).

Cervo and Bervian (1983) classify the research into three types: i) searching: consists in finding theoretical literature references in documents, taking notice and analyzing scientific contributions to the subject in question; ii) descriptive research: aims to observe, record, analyze and correlate facts or phenomena, without interfering in the analyzed environment, and may take various forms, such as exploratory studies, descriptive studies, case studies and survey; and iii) experimental research: is a form of research that directly manipulates the variables related to the object under study to determine the interaction between these variables and explain the causes of the phenomenon studied.

For the classification of this work, is taken as the base taxonomy by Vergara (2009), which, as previously presented, the ranks in two respects: on ends and as to means. As for the purpose, this study is classified as exploratory and descriptive. Exploratory, because although there are studies on tax evasion and tax authority in Brazil. Descriptive, because it aims to describe the State structure to punish tax evasion.

Through an exploratory and descriptive research, we seek to know the subject in greater depth in order to make it lighter or build important for the conduct of research questions.

\section{Results and Discussion}

\subsection{Tax evasion in Brazil}

In this last ten years, Brazil has a period of economics increase. The Gross Domestic Product (GDP) has a growing of 3\% per year and in 2013, it has $\mathrm{R} \$ 4,840$ trillion. Figure 1 shows this growing.

The high average growth enabled the Brazilian economy of a jump from 15th to 7 th in the world economy, according to the Applied Economics Institute (IPEA), in a period of only seven years. 


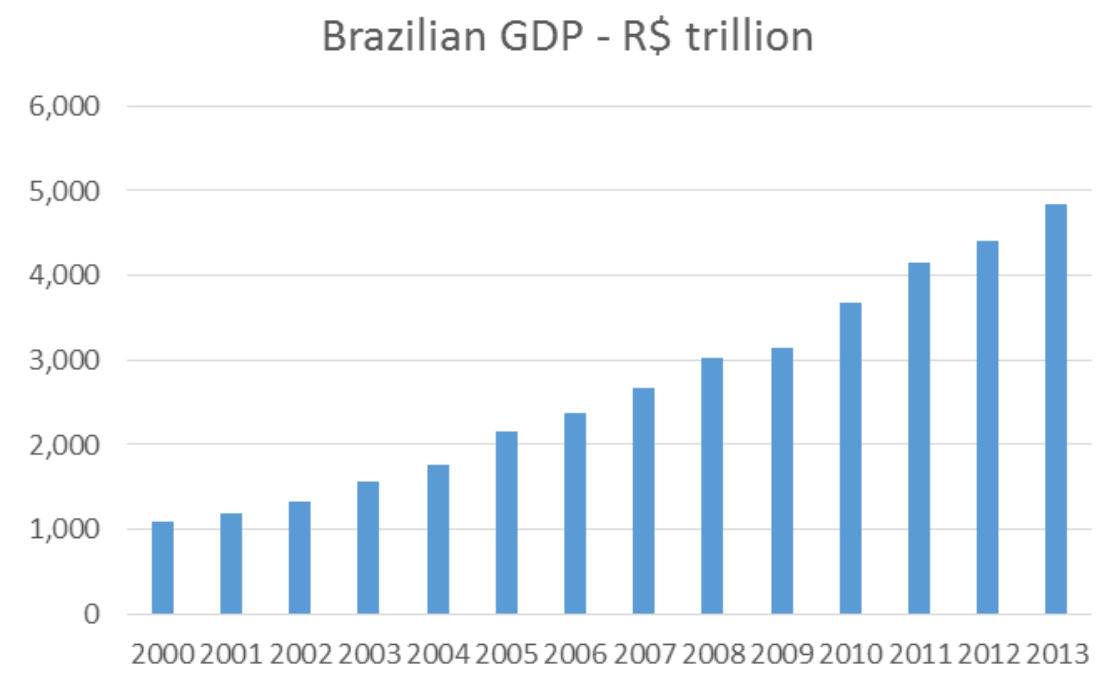

Figure 1 - Brazilian GDP

Source: Applied Economics Institute (IPEA).

One of the elements responsible for leveraging the Brazilian GDP growth is the collection of taxes and contributions that amounted, in $2013,36.42 \%$ of GDP to $\mathrm{R} \$ 1,138,326$ million according to a survey of Federal Revenue for the same year.

According to the Organization for Economic Cooperation and Development (OECD), in 2009, Brazil ranked 14th position in relation to countries with higher tax burden, reaching 34.5 percent of the Gross Domestic Product (GDP), second only to highly develop European countries. In 2012, the Tax Burden (CTB) reached 35.51\% of GDP, the highest ever recorded in the country. The distribution of these taxes is made as follows: the Federal Government gets $70.0 \%$ of total revenues, while the states are left with $24.4 \%$ and municipalities with $5.5 \%$.

Several types of taxpayers are taxed: individuals and companies about various forms of taxes. The main tax is calculated on income (IR), which is proportional to the level of income of the taxpayer. Companies, in addition to paying the tax on your income (income tax) also pay various other taxes such as the Tax on Industrialized Products (IPI), Tax on Goods and Services (ICMS), Service Tax (ISS) etc. Besides the taxes companies pay various taxes as the Social Contribution on Net Income (CSLL), Contribution to Social Security (COFINS), Social Integration Program (PIS) and Training program for the Civil Servants (PASEP). Table 1 shows the value of the main taxes and contributions paid by companies in Brazil from 2011 to 2013 . 


\section{Macrothink \\ International Journal of Accounting and Financial Reporting \\ ISSN 2162-3082 \\ 2017, Vol. 7, No. 1}

Table 1 - Value of the main taxes and contributions (in $\mathrm{R} \$$ million)

Main Taxes

Mar/11 to Feb/12

Mar/12 to Feb/13

Variation $\%$

IPI

47.643

45.399

$-4,71$

COFINS

159.928

178.208

11,43

Pis/Pasep

42.497

47.077

10,78

IR

108.222

113.208

4,61

R

60.556

59.175

$-2,28$

CSLL

Total amount

418.846

443.067

5,78

Source: Federal Authority, Brazil.

The tax collection has as main objective the maintenance and funding of welfare of population activities. It is expected then that in countries with high taxation - above $20 \%$ - the human development index exceed 0,800.

Despite the high GDP growth and huge tax revenues, the welfare of the population did not follow the same pace. According to Human Development Index (HDI) 2014, Brazil presents indices under developed country - below 0,800 -.

The relationship between tax burden and return to society through goods and services applied by the Brazilian government is inefficient, a fact that helps explain the high levels of tax evasion in the country (Table 2 ). 
Table 2 - Tax burden vc HDI - 2007

\begin{tabular}{lcc}
\hline Country & $\%$ GDP & HDI \\
\hline Argentina & 29 & 0,797 \\
Chile & 21,3 & 0,805 \\
Equator & 16,9 & 0,72 \\
Guatemala & 12,5 & 0,574 \\
Mexico & 11 & 0,77 \\
Peru & 17,4 & 0,725 \\
Brazil & 34,3 & 0,718 \\
\hline \hline
\end{tabular}

Source: United Nations.

The tax evasion in the last decade, showed an average of about 6\% of GDP in 2013 reaching its peak $10 \%$ of GDP, resulting in a liability of R $\$ 415$ billion into the public coffers (Table $3)$.

Table 3 - Amount of Tax evasion - R \$ billion

Year Amount of tax evasion

$2000 \quad \mathrm{R} \$ 85,04$

2001

$\mathrm{R} \$ 97,22$

2003

$\mathrm{R} \$ 130,51$

2005

$\mathrm{R} \$ 219,65$

2007

$\mathrm{R} \$ 214,52$

2009

$\mathrm{R} \$ 259,03$

2011

$\mathrm{R} \$ 331,51$ 
Source: Federal Authority, Brazil.

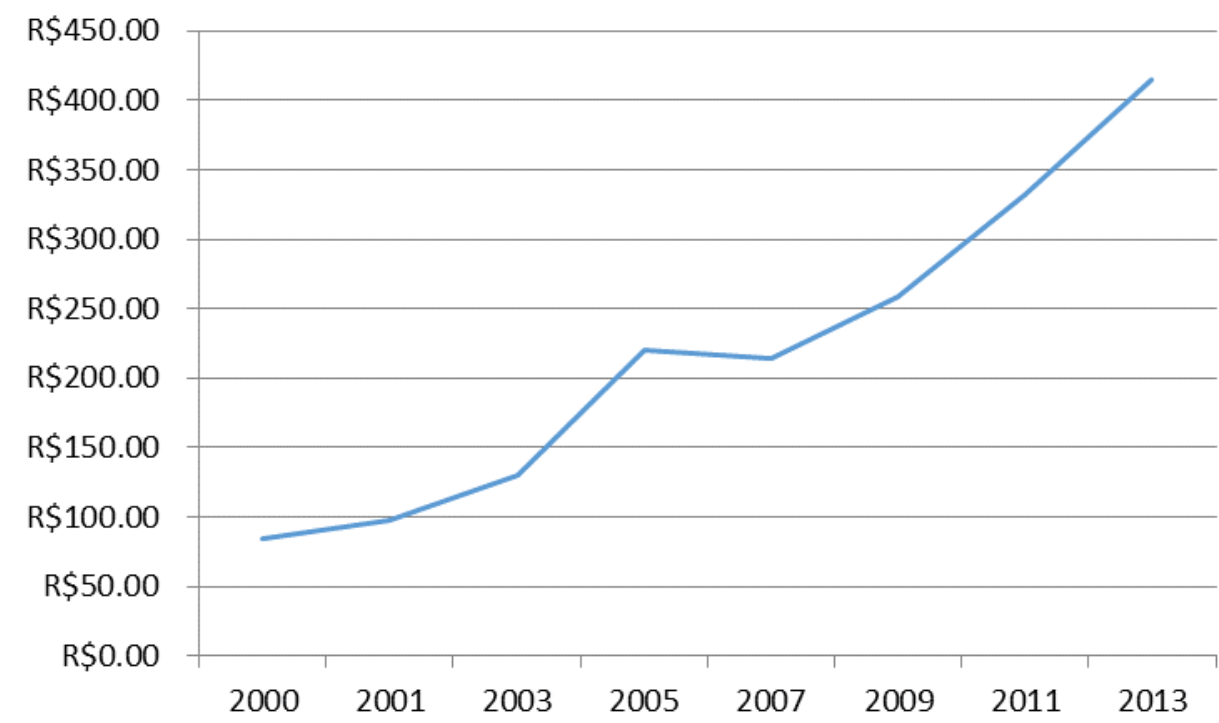

Figure 2 - Evolution of tax evasion in Brazil - R\$ billion

Source: Federal Authority, Brazil

Estimates put the Brazilian tax evasion around $15 \%$ to $40 \%$, which is already quite high. In the United States, it was estimated, in 2000, an evasion of about $17 \%$ in the case of Income Tax; in Russia, a country of similar economic dimensions to Brazil, there was a larger outflow of $42.7 \%$ for the year 1997 for Chile and this percentage was 26\% in 1995 .

At the micro level, the practice on a large scale and in different degrees of tax evasion ended up being the determining factor in competition between companies, negating the desired neutrality of taxation, which must be present in an efficient tax system. Indeed, in a context like this, the firm's competitive power in the market is due, in large part, on its ability to evade tax obligations, the dispute is also defined by its ability to maximize the rate of tax evasion and not only for their effort to produce goods efficiently and effectively. A survey conducted in 1982 by the Internal Revenue Service in Brasilia showed that of the 108 entities audited, $88.9 \%$ had results circumvented by $\mathrm{Cr}$ for each $\$ 1.00$ of tax declared, was an evasion of $\mathrm{Cr} \$ 093$.

\subsection{Brazilian Institutions to combat tax evasion}

The Federal Police Department (DPF) was created in 1944 due to the necessity of the Government to have a police structure covering the entire federal territory, acting in defense of property and rights of the Union and in the area of Public Safety. In 1960, the DPF in an attempt to resemble the police models in England, the United States and Canada, reshapes its structure, starting to have, effectively, operating throughout the country. The creation of the 


\section{Mll Macrothink}

International Journal of Accounting and Financial Reporting

ISSN 2162-3082

2017, Vol. 7, No. 1

Technical-Scientific Directorate and the National Institute of Criminology in 1962, did the research department of the police, which relies on science to help combat the various crimes against the State, arose.

The Criminology of DPF uses are scientific from various fields of human knowledge and a method to accomplish their assignment to investigate the crime through the study of material remains knowledge. Thus, as a particular area, the Criminality has also used borrowed methods of science. Sometimes with adaptations and other developing specific tools for research. For example, for analysis of drug chemistry is used. For analysis of graphics, the forensics used in part of physics, but needs to develop specific tools for such analysis.

The forensic report is, therefore, a written document in which the experts recorded in a comprehensive manner, content expertise and particularized aspects involving your object and searches for evidence for the completion of their work. This then is the fundamental part of the skill, the same being prepared by the expert for expressing its opinion on the Commission's technical issues and show where the operations performed on the matters before it are exposed, basing its opinion. It is in the finding that expert will describe and document the facts in order to develop their arguments and, ultimately, expose their conclusions.

The Federal Tax Authority (RFB) is another institution that investigates tax evasion in Brazil. It is responsible for determining the irregularities and pass on to the Public Ministry (releases that are not depicted as a crime against the order or tributary to the Federal Police (it has been a process of fiscal representation for criminal purposes).

The Federal Police (PF) investigates the crime of tax evasion, but at some point, it will also pass the RFB if you need to launch the credit. Therefore, the PF has the bias of the criminal sphere, more aggressive and less common, so practical.

The structure of sanctions RFB is described in the Law 9430/96 (penalties) and tax representation for criminal purposes. The crimes of fraud, collusion and evasion are in articles 71,72 and 73 of the Law 4502/64. That are attitudes that lead fine qualified $150 \%$ of the amount released, but as the factual issue of materiality should be solid, and fines thrown at RFB.

\section{Conclusion}

Brazilian tax evasion is very high. Tax evasion cause many problems for economics as budget realization, income distribution and not allocation of productive resources. It is necessary decrease tax evasion in Brazil to construct a country more just and modern.

Despite efforts to the fight against crimes pension Brazil faces several problems regarding the decreased levels of tax evasion in the country, the main structural nature such as soft laws, lack of skilled labor, inefficient methods of preventive combat and academic research. 


\section{Macrothink \\ International Journal of Accounting and Financial Reporting \\ ISSN 2162-3082 \\ 2017, Vol. 7, No. 1}

\section{References}

ALEXANDRE, R. 2013 Direito Tributário Esquematizado. 7. ed. rev e atual. Rio de Janeiro: Forense; São Paulo: Método.

ALM, J.; MARTINEZ-VAZQUEZ, J. "Institutions, Paradigms, and Tax Evasion in Developing and Transition Countries." In Public finance in developing and transitional countries : essays in honor of Richard Bird, edited by Richard M. Martinez-Vazquez Jorge Alm James Bird, 146-178. Cheltenham, UK; Northampton, Ma.: Edward Elgar Publishers, 2003.

BAGCHI, A. R.; BIRD, R.; DAS-GUPTA, A. An economic approach to tax administration reform. Discussion Paper 3, International Center for Tax Studies, University of Toronto, 1995.

BIRD, R.M. The administrative dimension of tax reform in developing countries. Durham, NC: Duke University Press, pp. 15-346, 1989.

CERVO, Amado Luiz; BERVIAN, Pedro Alcino. 1983. Metodologia científica. - 3. ed. - São Paulo : McGraw-Hill.

ELSTER, J. The Cement of Society, Cambridge, MA: Cambridge Univeristy Press, 1989.

GIAMBIAGI, F. 2002. Do déficit de metas as metas de déficit: a Política Fiscal do período 1995-2002. Pesquisa e Planejamento Econômico (PPE), v.32, n.1.

GOODE, R. Some economic aspects of tax administration. IMF Staff Papers, 28, 249-274, 1981.

MARTINS, I. G. S. 1998. Teoria da Imposição Tributária. 1. ed. São Paulo: Saraiva.

MOREIRA, A. M. 2003. Elisão e Evasão Fiscal - limites ao planejamento tributário. Revista da Associação Brasileira de Direito Tributário, Belo Horizonte, Vol 21, pp 11-17.

Oliveira, A.T. 2012. Proposta metodológica de perícia contábil para o crime de apropriação indébita previdenciária. Fundação Getúlio Vargas (FGV), Rio de Janeiro, 153p.

Vergara, S. C. 2009. Projetos e relatórios de pesquisa em Administração. - 11. ed. - São Paulo: Atlas.

\section{Glossary}

COFINS - Contribution to Social Security.

CSLL - Social Contribution on Net Income.

CTB - Tax Burden.

CTN - Brazilian Taxes Code.

DPF - Federal Police Department.

ICMS - Tax on Goods and Services. 


\section{Mll Macrothink

IPEA - Applied Economics Institute.

IPI - Industrialized Products Tax.

IR - Income Tax.

ISS - Services Tax.

PASEP - Training Program for the Civil Workers.

PF - Federal Police

RFB - Federal Tax Authority.

\section{Copyright Disclaimer}

Copyright for this article is retained by the author(s), with first publication rights granted to the journal.

This is an open-access article distributed under the terms and conditions of the Creative Commons Attribution license (http://creativecommons.org/licenses/by/3.0/). 